Araştırma Makalesi (Research Article)

Ayşe UZMAY

Buket KARATURHAN

Ege Üniversitiy, Faculty of Agriculture, Department of Agricultural Economics, 35100 Izmir/Turkey

e-mail:ayse.uzmay@ege.edu.tr

\section{Key Words:}

Women entrepreneurship in rural, agriculture policy, multinomial logistic regression, Turkey

\section{Anahtar Sözcükler:}

Kırsal alan, kadın girişimciliği, tarım politikası, multinomial lojistik regresyon, Türkiye

\title{
Study on the Factors Affecting the Choices of Initiative Areas for Prospective Rural Women Entrepreneurs in Izmir Province
}

\author{
İzmir Illinde Kırsal Kadın Girişimci Adaylarının Girişim Alanlarını \\ Etkileyen Faktörler Üzerine Bir Çalışma
}

Alınış (Received): 11.03.2015 Kabul tarihi (Accepted): 02.04.2015

\begin{abstract}
$T^{t}$

his study encompasses three important objectives. Firstly, to determine the socio-economic factors affecting the choice of initiative areas of the prospective women entrepreneurs in rural areas; secondly, to present their opinions about agriculture policies and finally; to give suggestions in order to increase the number of women entrepreneurs. "The promotion of women's entrepreneurship in rural areas' project" has been implemented for the first time in Turkey. Fifty women were successful in a test conducted by a Small and Medium Enterprises Development Organization, and primarily earned support for their projects. In this study, the fifty prospective women entrepreneurs were met in person and asked to fill in the questionnaire. The multinomial logistic regression model was used to determine the factors affecting the choice of work areas of these prospective entrepreneurs. Their choices were processing and marketing own agri-products, opening breakfast restaurants and using own food products there, and engaging in handicraft businesses, with the remaining wanted to work in other areas. According to the results of the multinomial logistic regression model, the variables that cause positive distinctiveness between the ones who wanted to open breakfast restaurants and the ones who wanted to process and market the agri-products were 'age' and 'being open to innovation'. However, the variables like 'whether the women are effective in agriculture policies or not', 'the frequency of participating in cultural activities' and the 'uncertainty in the prices of agri-products' had a negative distinctiveness.
\end{abstract}

\section{ÖZET}

Q u çalışmanın üç önemli amacı bulunmaktadır. İlki, kırsalda kadın girişimci Dadaylarının girişim alanı tercihlerini etkileyen sosyo-ekonomik, faktörlerin neler olduğunu belirlemek, ikincisi kadın girişimci adaylarının tarım politikalarıyla ilgili görüşlerini ve beklentilerini ortaya koymak, son olarak kırsalda kadın girişimcilerin artırılması, alternatif faaliyet alanları ve tarım politikalarındaki etkinliklerinin artırılması için önerilerde bulunmaktır. Türkiye'de “kırsal alanda kadın girişimciliğinin desteklenmesi projesi" uygulamaya ilk olarak konmuştur. Küçük ve Orta Ölçekli İşletmeleri Geliştirme ve Destekleme İdaresi Başkanlığı (KOSGEB) tarafından gerçekleştirilen girişimcilik testinde 50 kadın başarılı olmuştur ve öncelikli olarak projeleri desteklenmeye hak kazanmıştır. Bu araştırmada 50 kadın girişimci adaylarıyla yüz yüze anket yoluyla görüşülmüştür. Kadın girişimcilerin girişim alanı tercihlerini etkileyen faktörler belirlenirken multinominal logit modelden kullanılmıştır. Kadın girişimci adaylarının hazırladıkları proje konuları incelendiğinde tercih ettikleri faaliyet alanlarının tarım işletmelerinden elde ettikleri ürünleri işlemek ve pazarlamak, genelde kendi ürünlerini değerlendirerek kahvaltı yeri açmak, el sanatları ve diğer alanlar olduğu dikkati çekmektedir. Multinominal regresyon sonucuna göre, "kahvaltı yeri açmak" isteyenlerle, tarımsal ürününü işlemek ve pazarlamak isteyenler arasında yaş, yeniliklere açık olma pozitif ayırt edici özelliğe sahipken, kadınların tarım politikalarında etkin olup olmadığı görüşü, kültürel etkinliklere katılma sıklığı, tarım ürünleri fiyatlarında belirsizlik olup olmadığı görüşü negatif etkilemektedir. Diğer faaliyetler ile tarımsal ürününü işlemek ve pazarlamak isteyenler arasında ise coçukluğundan beri tarımsal faaliyette bulunanlar bulunmayanlara göre diğer faaliyet alanlarını tercih etme olasılığını azaltmaktadır. 


\section{INTRODUCTION}

In Turkey, $23.6 \%$ of the total employment force $(25,524,000)$ is women. $37.7 \%$ of the total of female's employees work in rural areas, whereas $31.05 \%$ of the total of male employees work there. $36.7 \%$ women of the total female population work in rural areas and $28 \%$ of them work in urban ones. However, the percentages of men, out of the total male population, working in both rural and urban areas is $71.6 \%$ and $71.2 \%$ respectively. $80 \%(3,130,000$ people $)$ of the women working in rural areas work in the agriculture sector. $19.93 \%$ of the women working in this sector work on a daily basis (regular and casual employees), $0.38 \%$ of them as employers, $13.45 \%$ of them work for themselves (own account workers), and $66.26 \%$ of them work unpaid as a family employee (TÜiK, 2014). The low ratio of women in the total employment figures, and the significant part of women's work being unpaid as family employees, makes it essential to take the necessary precautions to protect the female workforce and to produce policies to create economic value.

There are many organizations in Turkey that support the projects aimed at female entrepreneurship. These are the General Directorate of Women's Status, the Turkish Business Council, the Small and Medium Enterprises Development Administration (KOSGEB), the South Eastern Anatolia Project, Union of Chambers and Commodity Exchanges of Turkey, the Turkish Confederation of Tradesmen and Artisans of Turkey, the Association for Women Entrepreneurs, the Foundation for the Support of Women's Work, the Turkish Grameen Microcredit Project, and the Turkish Development Foundation (Iplik, 2012, Soysal, 2013). In particular, the European Union initiatives, the OECD, and the UN supporting female entrepreneurship, have led to progress in this area in Turkey.

Considering the international literature on women's entrepreneurship in rural areas, recent studies have mostly focused on utilizing of microcredit and the factors affecting women's entrepreneurship. According to the study conducted by Ahmed, F. et. al, (2011) in Bangladesh, the proportion of the rural women, with credit, who have contributed to their family income, is much higher (19\%) than that of rural women without credit (10\%). The results of the multiple regression analysis in the same study showed that there were strong positive effects when considering the age of the women, their level of education, the family size, the earning member in the family, the occupation of the women, and also the monthly income of the women. In contrast, the marital status of the women had a strong negative effect. However, it can be perceived that the micro credit programs only help the rural women borrowers to survive, and do not help them to develop entrepreneurial skills (Afrin, et al., 2008). The financial management skills and the group identity of the women borrowers have a significant relationship with the development of rural women entrepreneurship in Bangladesh. The result of a study by Anthopoulou (2010) in Greece regarding rural women in agrofood production showed that the women started up their businesses making use of tacit knowledge and know-how, and the family character of the business minimized the entrepreneurial risk. In another study in Iran (Hosseini et al., 2009), it was discovered that contact with agricultural experts was the main influencing factor in the entrepreneurial activities of rural women. Kumbhar (2013) reported that successful entrepreneurs are always the role model in society for women who have the ability for entrepreneurship and lead to them undertaking economic activities to prove their ability. Unfortunately, there is no sufficient provision of such type of interaction to inculcate knowledge and provide experiences for successful women entrepreneurs. Studies in India have shown that rural entrepreneurship is the answer in removing the rural poverty there, but the problem is that most of the rural youth do not think of entrepreneurship as a career option (Saxena, 2012; Parveen and Hundekar S.G. 2012).

In the recent Turkish academic literature, some studies have analyzed the factors affecting female entrepreneurship (Yetim, 2012; Tamer, 2013; Soysal A.; 2013, Öztürk, Akkoc, 2013), whereas some of them focused on women in rural areas and female entrepreneurship (Gülçubuk, 1999; Kantar, 1999; Kızılaslan and Yamanoğlu, 2010; Iplikci, 2012; Kızılaslan and Erçoban, 2013; Soysal, 2013). A relatively small number of studies have been conducted in this field in Turkey; and a limited amount of them have focused on the differences between entrepreneurs and nonentrepreneurs. However, no study in Turkey has ever concentrated on the possible areas that the prospective women entrepreneurs would like to work in or the factors affecting their preferences. It's important to determine these factors as it will help in devising and shaping both policies and projects in rural areas.

The basic objectives of this study are:

- To determine the socio-economic factors affecting the choice of initiative areas of the prospective women entrepreneurs in rural areas 
- To present their opinions about agriculture policies and their expectations from the policies

- To give suggestions in order to increase the number of female entrepreneurs in rural areas, alternative sectors they can work in, and to improve the effectiveness of agriculture policies.

\section{MATERIAL and METHOD}

'The Promotion of Women Entrepreneurship in Rural Areas' project has been implemented for the first time, and Izmir was chosen as the pilot province by the Food, Agriculture and Livestock Ministry. Izmir is the third biggest metropolitan city in Turkey, and is located in the Aegean Region. Its square measure is 12,012 square kilometers. According to the data from 2013 , its population is approximately 4,061 thousand. $11 \%$ of the population is employed in the agriculture sector. The Izmir plant and animal production rate within the total production rate in Turkey is 3 and 4 respectively. 133 women applied to take part in the project. Out of this number, 50 women passed the prospective entrepreneur test conducted by KOSGEB who gave financial support them for their projects. The support included a stipend of up to $30,000 \mathrm{TL}$; and interest-free credit of up to 70,000 TL due after two years. The prospective 50 entrepreneurs also got 10 days of training and prepared projects for their desired work areas. Within this study, a survey was conducted with the fifty selected prospective women entrepreneurs, in person. The survey was conducted in February, 2014. The data received from the survey is the primary material for the study. The other studies related to women in rural areas and statistics within this context constitute the secondary material of the study.

The Multinomial (polytomous) Logistic Regression model was used in order to determine the factors affecting the choice of work area of the prospective female entrepreneurs. The preferred work area was taken as a dependent variable. Three work areas were taken into consideration: the processing and marketing of agri-products, opening breakfast restaurants, and others. The handicrafts sector was considered in 'others'. The reason for this classification was that the women in the other two categories wanted to use their own grown agri-products in their businesses.

In the multinomial logistic regression, for a dependent variable with the $M$ categories, the $M-1$ number of equations, representing the relationship among the dependent and independent variables, and comparing each category with a reference category are required. For each category of the dependent variable, except for the reference category, an equation can be written as follows (Menard, Scott W., 2002);

$$
g_{h}\left(X_{1}, X_{2}, \ldots, X_{k}\right)=e^{\left(a_{h}+b_{h 1} X_{1}+b_{h 2} X_{2}+\ldots .+b_{h k} X_{k}\right)} \quad h=1,2, \ldots ., M-1
$$

where the subscript $k$ refers to specific independent variables, $X$ and the subscript $h$ refers to the specific values of the dependent variable, and $Y$ for the reference category, $g_{0}\left(X_{1}, X_{2}, \ldots, X_{k}\right)=1$. The probability that $Y$ is equal to any value $h$ other than the excluded value $h \dot{d}$ s:

$$
\begin{aligned}
& \qquad P\left(Y=h \mid X_{1}, X_{2}, \ldots, X_{k}\right)=\frac{e^{\left(a_{h}+b_{h 1} X_{1}+b_{h 2} X_{2}+\ldots+b_{h k} X_{k}\right)}}{1+\sum_{h=1}^{M-1} e^{\left(a_{h}+b_{h 1} X_{1}+b_{h 2} X_{2}+\ldots+b_{h k} X_{k}\right)}} \\
& h=1,2, \ldots, M-1, \quad \text { (0.2) } \\
& \text { For the excluded category } h_{0}=\text { Mor } 0 \\
& \qquad P\left(Y=h_{0} \mid X_{1}, X_{2}, \ldots, X_{k}\right)=\frac{1}{1+\sum_{h=1}^{M-1} e^{\left(a_{h}+b_{h 1} X_{1}+b_{h 2} X_{2}+\ldots+b_{h k} X_{k}\right)}} \\
& \qquad h=1,2, \ldots, M-1 .(0.3)
\end{aligned}
$$

The dependent variable $(Y)$ shows the preferred work area of the entrepreneurs. 'The processing and marketing of agri-products', the reference category, is coded as 0 , 'opening a breakfast restaurant' is coded as 1, and 'other work areas' as 2. Therefore, created model is consisting of three categories in the study. There are two logit functions in the model. In the first function, the first category, 'opening a breakfast restaurant' is compared with the reference category, whereas in the second function, the second category, 'other work areas' is compared with the reference category. The 'rocessing and marketing of agriproducts' category is taken as a reference category, as it is the most preferred work area. 
There were twelve independent variables $(X)$ included in this study. The digits and percentages related to the explanatory variables are presented in Table 1. Age, education, income level, the areas where women spend most of their time, openness to innovation, frequency of participating in cultural activities, association memberships, working in agriculture since childhood, and still working in some type of agricultural activity, which factors primarily affect their business plan, whether they think that women play an active role in agricultural activities or not, and whether they think that the prices of agriproducts are uncertain or not, are considered as explanatory variables in the model.

Table 1. Determination of VAR lag-structur

\begin{tabular}{|c|c|c|c|c|}
\hline Dependet variable $(\mathrm{Y})$ & Type of Variable & Description & Frequency & Percent(\%) \\
\hline & Categorical & $\begin{array}{l}1 \text { Process and marketing their own } \\
\text { produced agri-products } \\
2 \text { Open to breakfast restaurants } \\
3 \text { Other activities }\end{array}$ & $\begin{array}{l}24 \\
15 \\
11\end{array}$ & $\begin{array}{l}48.0 \\
30.0 \\
22.0\end{array}$ \\
\hline \multicolumn{5}{|l|}{ Independent variables $(\mathrm{X})$} \\
\hline \multirow[t]{4}{*}{ Age (AGE) } & Ordinal & $1: 20-30$ & 7 & 14.0 \\
\hline & Categorical & $2: 31-40$ & 15 & 30.0 \\
\hline & & $3: 41-50$ & 19 & 38.0 \\
\hline & & $4: 51-65$ & 9 & 18.0 \\
\hline \multirow[t]{4}{*}{ Education (EDU) } & Ordinal & 1: primary school & 17 & 34.0 \\
\hline & Categorical & 2: secondary school & 6 & 12.0 \\
\hline & & 3: high school & 15 & 30.0 \\
\hline & & 4: universty & 12 & 24.0 \\
\hline \multirow[t]{5}{*}{ Income level (TL) (INCM) } & Ordinal & $1: 1500-3000$ & 41 & 82.0 \\
\hline & Categorical & $2: 3001-4000$ & 4 & 8.0 \\
\hline & & $3: 4001-5000$ & 2 & 4.0 \\
\hline & & 4:5001-6000 & 1 & 2.0 \\
\hline & & $5: 6001 \leq x$ & 2 & 4.0 \\
\hline \multirow{2}{*}{$\begin{array}{l}\text { The areas where spend most of their lives } \\
\text { (LVS) }\end{array}$} & Categorical & 0 : provincial and district & 22 & 44.0 \\
\hline & & 1: villages and towns & 28 & 56.0 \\
\hline \multirow{4}{*}{$\begin{array}{l}\text { Oppenes to innovation } \\
\text { (INNO) }\end{array}$} & Ordinal & 1: disagree & 1 & 2.0 \\
\hline & Categorical & 2: neutral & 2 & 4.0 \\
\hline & & 3: agree & 8 & 16.0 \\
\hline & & 4: strongly agree & 38 & 76.0 \\
\hline \multirow{4}{*}{$\begin{array}{l}\text { Freuquancy of paticiping in cultural } \\
\text { activities (CLTR) }\end{array}$} & Ordinal & 1: no & 6 & 12.0 \\
\hline & Categorical & $2: 2-4$ & 27 & 54.0 \\
\hline & & 3: 4-6 & 8 & 16.0 \\
\hline & & $4: 6 \leq$ & 9 & 18.0 \\
\hline \multirow{4}{*}{$\begin{array}{l}\text { Assocations membership } \\
\text { (MMS) }\end{array}$} & Ordinal & $1:$ no & 30 & 60.0 \\
\hline & Categorical & $2: 1$ & 9 & 18.0 \\
\hline & & $3: 2$ kere & 4 & 8.0 \\
\hline & & $4: 3 \leq x$ & 7 & 14.0 \\
\hline \multirow{4}{*}{$\begin{array}{l}\text { Which factor primarily effects on their } \\
\text { business plan (PLAN) }\end{array}$} & Categorical & 1: higher of risk & 2 & 4.0 \\
\hline & & 2: the lack of competition & 4 & 6.0 \\
\hline & & 3: a well-known line of business & 27 & 54.0 \\
\hline & & 4: high profability & 18 & 36.0 \\
\hline \multirow{2}{*}{$\begin{array}{l}\text { Working in agriculture since childhood } \\
\text { (CHILD) }\end{array}$} & Dichotomus & 0: no & 25 & 50.0 \\
\hline & & $1:$ yes & 25 & 50.0 \\
\hline \multirow{3}{*}{$\begin{array}{l}\text { Still working in some type of agricultural } \\
\text { activity } \\
\text { (ACTVTY) }\end{array}$} & Categorical & 0:no & 6 & 12.0 \\
\hline & & 1:sometimes & 11 & 22.0 \\
\hline & & 2:yes & 33 & 66.0 \\
\hline \multirow{2}{*}{$\begin{array}{l}\text { Think that women play an active role in } \\
\text { agriculture policy (ARL) }\end{array}$} & Dichotomus & 0: no & 36 & 72.0 \\
\hline & & $1:$ yes & 14 & 28.0 \\
\hline \multirow{3}{*}{$\begin{array}{l}\text { Think that the prices of agri-products are } \\
\text { uncertain or not } \\
\text { (PRICE) }\end{array}$} & Ordinal & 1:strongly disagree & 31 & 62.0 \\
\hline & Categorical & 2:disagree & 17 & 34.0 \\
\hline & & 3:neutral & 2 & 4.0 \\
\hline
\end{tabular}




\section{RESULTS and DISCUSSION}

When the project areas are observed according to the suggested projects by the prospective female entrepreneurs, it is clear that their preferred areas are processing and marketing their own produced agriproducts $(48 \%)$, opening breakfast restaurants and using their own products there $(30 \%)$, working in the handicraft business $(12 \%)$, and (10\%) other areas (energy production, website design, marketing agency, etc.). Almost $33.3 \%$ of the ones who wanted to engage in processing and marketing the agriproducts intended to focus on animal products, $37.5 \%$ on olives and olive oil; and the remaining $29.2 \%$ intended to focus on fruits and vegetables. The regional differences in the production patterns in Turkey led the women entrepreneurs in the rural areas to focus on different agri-products. According to a study in Osmaniye, $40 \%$ of female entrepreneurs were engaged in livestock breeding, 30\% were associated with handicrafts, and $25.8 \%$ were working in the food sector (such as pickle and jam making) (Iplikci, 2012).

As far as the area where they spend most of their time is concerned, it was revealed that almost $54 \%$ of the women spend most of their time in villages, $4 \%$ of them in towns, $38 \%$ of them in counties, and $4 \%$ of them in cities. It was determined that no statistically significant difference was found between the proposed projects of the female entrepreneurs and the area where they spend most of their time (Pearson Chi-Square 10.268, p 0.329>0.05).

$48 \%$ of the women living in villages were intending to process agri-products, and $33 \%$ of them were planning to open breakfast restaurants, whereas $50 \%$ of the women living in towns wanted to focus on the breakfast sector. $52.6 \%$ of the women living in counties were planning to process and market the agri-products, and $26.3 \%$ of them were intending to open breakfast restaurants.

Almost $66 \%$ of the producers of agri-products stated that they had enough capital to fund their projects at the initial stage. In particular, the $91.7 \%$ of the ones who were planning to process the agriproducts stated that they had this initial capital. However, $100 \%$ of the ones who were intending to engage in -handicrafts businesses did not state that they had any initial capital. $73.3 \%$ of the ones intending to open breakfast restaurants stated that they had enough capital for it. Consequently, there was a statistically significant difference found between the work areas of the proposed projects and having capital for the initial stage (Pearson ChiSquare28.758, p $0.00<0.05)$. The desired budget for each project ranged from $13,025 \mathrm{TL}$ to $600,000 \mathrm{TL}$.
There was no significant difference found between the project work area and the desired budget (Oneway Anova, f 0.640, p 0.593>0.05).

When the views of entrepreneurs on their closeness to their ideals in many aspects of life were analyzed, it was observed that $23 \%$ of them chose "strongly agree", 29\% chose "agree", $8.3 \%$ chose "indecisive", $6.3 \%$ chose "disagree", and $8.3 \%$ chose "strongly disagree". No statistical findings were encountered between the work areas of the entrepreneurs and their views on their closeness to their ideals. Pearson Chi-Square 11.941, p 0.450>0.05). When the question of 'what do you think is the most important characteristic in an entrepreneur?' was asked, $42 \%$ of the female entrepreneurs answered courage, whereas $58 \%$ of them said innovation. There was no statistically significant difference found between this variable and the preferred work area (Pearson Chi-Square 2.381, p 0.497>0.05).

Only $18 \%$ of the prospective female entrepreneurs had a membership to a cooperative; and $78 \%$ of the cooperatives were agriculture cooperatives. There was no statistically significant difference found between this variable and the dependent variable (Pearson ChiSquare $0,389, p$ 0.942>0.05). Here, it is important to note that there was no trend to obtain a membership for nascent women cooperatives. Currently, there are 93 women cooperatives in Turkey; and $74 \%$ of them are business cooperatives (Özdemir and Yılmaz, 2010). When their amount of participation in agricultural activities was asked, $69.4 \%$ of the female entrepreneurs answered that they participate, $8 \%$ of them said they did not, and $22 \%$ of them answered that they participate occasionally. In Turkey, the women, and especially those who belong to the families that had less land participated in all the stages of crop and animal production (Gülçubuk, 1999; Kızılaslan and Yamanoğlu, 2010a; Kızılaslan and Erçoban, 2013).

In a study conducted in Tokat, a province in Turkey, it was revealed that couples make mutual decisions on children, education, and shopping, whereas in the matters of family budget, men were more influential. In the decisions relating to agricultural production, $61 \%$ of the women participate, and $19.88 \%$ of them participate partially; whereas $18.7 \%$ of them don't participate at all (Kızılaslan and Yamanoğlu, 2010). This study shows that with decisions related to agricultural production, $68 \%$ of the prospective women entrepreneurs take them mutually with their husbands, $12 \%$ of them are influenced by family elders and $8 \%$ of them leave the decisions to their husbands while $8 \%$ of them take the 
decisions themselves; and 4\% of them don't participate in any type of agricultural activity.

When the question as to the effectiveness of women in agriculture policies was asked, $28 \%$ of them answered that they were effective. Categorizing on the basis of desired work areas, $25 \%$ of the women who wanted to process and market their own grown agri-products, $33 \%$ of those who wanted to open breakfast restaurants, again $33 \%$ of those who wanted to engage in handicraft businesses, and 20\% of the those who wanted to work in other areas answered that women were indeed effective in agriculture policies. $86 \%$ of the prospective female entrepreneurs gave a negative answer to the question of their satisfaction with the agricultural policies applied in Turkey.

When their opinion on agricultural policy types that should be devised by the government was asked, $48 \%$ of them said that the subsidies should be increased, $20 \%$ said that measures should be taken to ensure an appropriate market prices for the agriproducts, $4 \%$ of them stressed the need for policies focusing on determining regional production patterns, $4 \%$ of them were in favor of banning the import of agri-products, $2 \%$ of them were of the view that measures should be taken to improve the marketing of local agri-products, and $2 \%$ were in favor of increasing the number of workshops in order to educate the farmers. However, $10 \%$ of them did not state any idea. It is important to note that no statistically significant difference was found between whether they participated in any type of agricultural activity or not, or the effectiveness of the women in agricultural policies. However, $30.3 \%$ of those who regularly participated in any type of agricultural activities, and $27.3 \%$ of those who participated irregularly, thought that women were effective in agripolicies.

Results of Multinomial Regression: The independent variables included in the multinomial logit model, are given in Table 1. The estimated results of the model are provided in both Tables 2 and 3 . The likelihood ratio test of the model shows that the model is statistically significant. According to the results, there was a significant relationship between the dependent and independent variables. In this study, the dependent variable represents the preferred work areas of the prospective female entrepreneurs. It was divided into three categories: the processing and marketing of own agri-products, opening a breakfast restaurant, and other work areas. The handicraft sector is considered in 'others'. The processing and marketing of agri-products', and the reference category, is coded as 0 , 'opening a breakfast restaurant' is coded as 1, and 'other work areas' is coded as 2 . In the first function, the first category, 'opening a breakfast restaurant' is compared with the reference category, whereas in the second function, the second category, 'other work areas' is compared with the reference category.

Table 2. Model Fitting Information

\begin{tabular}{|c|c|c|c|c|}
\hline \multirow{2}{*}{ Model } & \multirow{2}{*}{$\begin{array}{l}\text { Model Fitting Criteria } \\
-2 \text { Log Likelihood }\end{array}$} & \multicolumn{3}{|c|}{ Likelihood Ratio Tests } \\
\hline & & Chi-Square & df & Sig. \\
\hline Intercept Only & 96.627 & & & \\
\hline Final & 54.709 & 41.918 & 24 & $.013^{*}$ \\
\hline Pseudo R-Square & Cox and Snell 0.590 & Nagelkerke 0.677 & McFadden 0.434 & \\
\hline \multicolumn{5}{|c|}{ Likelihood Ratio Tests } \\
\hline \multirow[t]{2}{*}{ Effect } & Model Fitting Criteria & & od Ratio Tests & \\
\hline & $\begin{array}{c}-2 \text { Log Likelihood of Reduced } \\
\text { Model }\end{array}$ & Chi-Square & $\mathrm{df}$ & Sig. \\
\hline Intercept & 59.380 & 4.671 & 2 & .097 \\
\hline LVS & 57.366 & 2.657 & 2 & .265 \\
\hline CHILD & 62.310 & 7.602 & 2 & $.022^{*}$ \\
\hline EDU & 57.058 & 2.350 & 2 & .309 \\
\hline INCM & 58.013 & 3.305 & 2 & .192 \\
\hline ARL & 59.694 & 4.986 & 2 & $.083^{* *}$ \\
\hline AGE & 66.629 & 11.921 & 2 & $.003^{*}$ \\
\hline CLTR & 60.274 & 5.565 & 2 & $.062^{* *}$ \\
\hline MMS & 54.821 & .112 & 2 & .946 \\
\hline ACTVTY & 58.610 & 3.901 & 2 & .142 \\
\hline PRICE & 58.997 & 4.289 & 2 & .117 \\
\hline PLAN & 56.051 & 1.342 & 2 & .511 \\
\hline INNO & 62.207 & 7.498 & 2 & $.024^{*}$ \\
\hline
\end{tabular}

* Significant at $\mathrm{p}<0.05$. ${ }^{* *}$ Significant at $\mathrm{p}<0.10$. 
The results of the first equation show (Table 3 ), there is distinctiveness present between those who wanted to open breakfast restaurants, and those who wanted to process and market the agri-products. The explanatory variables such as age $(P<0.05)$, whether the women were effective in agri-policies or not $(P<0.10)$, the frequency of participating in cultural activities $(P<0.10)$, whether there was uncertainty in the prices of agri-products or not $(P<0.10)$, and openness to innovation $(P<0.05)$ are distinctive. Age effects 'openness to innovation' positively; but it has a negative effect on variables such as 'whether the women were effective in agri-policies or not', the 'frequency of participating in cultural activities' and the 'uncertainty in the prices of agri-products'. With a one unit increase 'age' variable, the probability of opening a breakfast restaurant increased 26.70 times. However, with a one unit increase in 'openness to innovation', its probability increases 20 times. With a one unit increase in the opinion that the women were effective in agricultural policies, the probability of opening a breakfast restaurant decreased 21.27 times; whereas its probability decreased 4.36 times with a one unit increase in 'the frequency of participating in cultural activities'. Moreover, its probability also decreased 10.10 times with a one unit increase in the opinion that the prices of agri-products were uncertain. The results of the second equation were used to identify the distinction between those who wanted to process and market the agri-products and those who wanted to engage in 'other work areas'. According to them, with a one unit increase in the engagement with some types of agricultural activities since childhood, the probability of choosing 'other work areas' decreased 27.02 times.

Table 3. Parameter estimates of multinomial logistic regression results.

\begin{tabular}{|c|c|c|c|c|c|c|c|c|c|}
\hline \multirow[b]{3}{*}{$\begin{array}{l}\text { Open to beakfast } \\
\text { restaurants (1) }\end{array}$} & \multirow[b]{3}{*}{ Intercept } & \multirow[t]{2}{*}{ B } & \multirow[t]{2}{*}{ Std. Error } & \multirow[t]{2}{*}{ Wald } & \multirow[t]{2}{*}{$\mathrm{df}$} & \multirow[t]{2}{*}{ Sig. } & \multirow{3}{*}{$\begin{array}{l}\operatorname{Exp}(B) \\
\text { Upper } \\
\text { Bound }\end{array}$} & \multicolumn{2}{|c|}{$\begin{array}{l}\text { 95\% Confidence Interval } \\
\text { for } \operatorname{Exp}(\mathrm{B})\end{array}$} \\
\hline & & & & & & & & Lower Bound & $\begin{array}{l}\text { Upper } \\
\text { Bound }\end{array}$ \\
\hline & & 2.479 & 9.486 & .068 & 1 & .794 & & & \\
\hline \multirow{12}{*}{ 1st Eq. estimates } & LVS & 2.342 & 1.680 & 1.943 & 1 & .163 & 10.399 & .386 & 279.904 \\
\hline & CHILD & -1.901 & 1.292 & 2.164 & 1 & .141 & .149 & .012 & 1.881 \\
\hline & EDU & 1.069 & .906 & 1.394 & 1 & .238 & 2.914 & .494 & 17.201 \\
\hline & INCM & .339 & .839 & .164 & 1 & .686 & 1.404 & .271 & 7.271 \\
\hline & ARL & -3.054 & 1.558 & 3.842 & 1 & $.050^{* *}$ & .047 & .002 & 1.000 \\
\hline & AGE & 3.285 & 1.452 & 5.119 & 1 & $.024^{*}$ & 26.703 & 1.552 & 459.588 \\
\hline & CLTR & -1.476 & .872 & 2.866 & 1 & $.090^{* *}$ & .229 & .041 & 1.262 \\
\hline & MMS & -.264 & .838 & .099 & 1 & .753 & .768 & .149 & 3.971 \\
\hline & ACTVTY & .222 & .902 & .061 & 1 & .805 & 1.249 & .213 & 7.313 \\
\hline & PRICE & -2.315 & 1.238 & 3.497 & 1 & $.061^{* *}$ & .099 & .009 & 1.118 \\
\hline & PLAN & -.331 & .953 & .121 & 1 & .728 & .718 & .111 & 4.651 \\
\hline & INNO & 2.996 & 1.357 & 4.874 & 1 & $.027^{*}$ & 19.998 & 1.399 & 285.758 \\
\hline Other activities (2) & Intercept & 16.972 & 9.184 & 3.415 & 1 & .065 & & & \\
\hline \multirow{12}{*}{ 2st Eq. estimates } & LVS & -.119 & 1.261 & .009 & 1 & .925 & .888 & .075 & 10.508 \\
\hline & CHILD & -4.019 & 1.924 & 4.363 & 1 & $.037^{*}$ & .018 & .000 & .781 \\
\hline & EDU & -.339 & .688 & .243 & 1 & .622 & .712 & .185 & 2.743 \\
\hline & INCM & -1.258 & .890 & 1.998 & 1 & .158 & .284 & .050 & 1.627 \\
\hline & ARL & -.799 & 1.262 & .401 & 1 & .526 & .450 & .038 & 5.331 \\
\hline & AGE & -.167 & .752 & .049 & 1 & .824 & .846 & .194 & 3.697 \\
\hline & CLTR & .966 & 1.090 & .785 & 1 & .376 & 2.627 & .310 & 22.253 \\
\hline & MMS & -.153 & .739 & .043 & 1 & .836 & .858 & .202 & 3.651 \\
\hline & ACTVTY & -1.709 & 1.066 & 2.572 & 1 & .109 & .181 & .022 & 1.462 \\
\hline & PRICE & -1.471 & 1.265 & 1.352 & 1 & .245 & .230 & .019 & 2.742 \\
\hline & PLAN & -.999 & .897 & 1.241 & 1 & .265 & .368 & .064 & 2.136 \\
\hline & INNO & -1.237 & 1.834 & .455 & 1 & .500 & .290 & .008 & 10.563 \\
\hline
\end{tabular}

a The reference category is: process and marketing their own produced agri-products (0). $\left.{ }^{*}\right)$ Significant 


\section{CONCLUSION}

According to the results of the multinomial logistic regression, the variables that cause positive distinctiveness between those who wanted to open breakfast restaurants and those who wanted to process and market the agri-products, are 'age' and 'being open to innovation'. However, the variables such as 'whether the women are effective in agripolicies or not', 'the frequency of participating in cultural activities' and 'uncertainty in the prices of agri-products' had a negative distinctiveness. The women who had been engaged in agriculture since childhood were less likely to choose other areas when compared to processing and marketing agri-products. Based on the results, the following recommendations can be given in order to improve women entrepreneurship in rural areas:

- A large percentage $(48 \%)$ of the women showed an intention to process and market their own grown agri-products. Most had been working in the agriculture sector since childhood, and thought that women are effective in agriculture policies. It is important to note that the women did not have a membership of female cooperatives; and also the cooperatives were not developing in the rural areas in Izmir. In order to be effective in agriculture policies and be strong economically, the women should be encouraged to take up membership with the cooperatives. Within this concept, it is important to raise women's awareness regarding the importance of organizations, and to thus encourage them in this direction.

- The women interested in the other areas such as handicrafts, mentioned a shortage of capital. These women should be given information about credit, microcredit programs, and other financing instruments.

\section{REFERENCES}

Afrin, S., I. Nazrul, and U. A. Shahid 2008. A Multivariate Model of Micro Credit and Rural Women Entrepreneurship Development in Bangladesh", International Journal of Business and Management, 3 (8): 169-185.

Ahmed, F., C. Siwar and N.A.H. Idris, 2011. Contribution of rural women to family income through participation in microcredit: an empirical analysis. Am. J. Applied Sci., 8: 238-245.

Anthopoulou, T., 2010. Rural women in local agrofood production: Between entrepreneurial initiatives and family strategies. A case study in Greece, Journal of Rural Studies, 26 (4): 394-403.

Esen E., 2013. Avrupa Birliği ve Türkiye'de Kırsal Kadının Durumu ve Almanya'dan Proje Uygulama Örnekleri, (Rural Women's Status and Project Implementation Examples from Germany in
- Those who wanted to open breakfast restaurants also complained about the price instability in agriproducts. Thus, different marketing strategies should be developed to market the products directly from the producer to the consumer in the breakfast restaurants.

- Almost $37.5 \%$ of the women prepared projects on the marketing of olives and olive oil. Therefore, the similarities among the products, especially in the Aegean region, make it easier to educate the women through market specific training programs. In order to market their products more effectively, they can be encouraged to create their own webpage.

- The female entrepreneurs in rural areas should be encouraged to engage in higher income generating businesses instead of only traditional ones; and different courses may also be arranged in this regard.

- It is important to disseminate the results of this project to the whole of Turkey. However, for a long lasting effect, the social and economic impact of the project on the women should be analyzed carefully; and the necessary support should be provided.

- The success stories of women entrepreneurs should be communicated to other prospective women entrepreneurs.

\section{Acknowledgements}

This research was conducted in Turkey and encompasses a pilot project in Izmir called 'The promotion of women entrepreneurship in rural areas' by the Food, Agriculture, and Livestock Ministry in Turkey. We thank the ministry for their continuing support.

European Union and Turkey), Ankara Avrupa Calismalari Dergisi, 12(1): 105-127.

Gülçubuk, B., 1999. Tarımsal Üretimde ve Kırsal Kalkınmada Kadının Yeri ve Önemi (Importance and The Place of Women in Agricultural Production and Rural Development), Tarım ve Köy Dergisi, Sayı:125: 36-41

Hosseini, S.J.F, S.M. Mirdamadi and G.R.H.H. Nejad., 2009. Extension and education factors influencing the success of entrepreneurship among rural women in Northern Iran. Research Journal of Biological Sciences,4(9):976-973.

Iplik, E., Osmaniye İli Kırsalında Kadın Girişimciliği (Women Entrepreneurship in Rural Areas of Osmaniye) , Çukurova Üniversitesi Fen Bilimleri Enstitüsü, Tarım Ekonomisi Anabilim 
Dalı, Doktora Tezi, Adana 2012, s. 158. http://traglor.cu.edu.tr/objects/objectFile/dtqC8AqH-189201348.pdf

Kantar, M., 1999. Girişimcilik ve kırsal kadınlar (Entrepreneurship and rural women) Tarım Ekonomisi Dergisi, 4: 29-42.

Kizlaslan N. and M. Ercoban, 2013. A Comparative analysis of paticipation of women to agricultural activities and utilization possibilities of agricultural extension (survey at center of Tokat province), BioSciences, RRBS, 7(9):349-362,

Kızılaslan, N. and Yamanoğlu, A., 2010a, Participation of Women in Rural Areas of Agricultural Production and Domestic Matters in Decision-Making: A Case Study for Tokat Province, The Journal of International Social Research, 3(13):154-166 (In turkisch)

Kızılaslan, N. and A.Yamanoğlu, 2010b, Social Gender Analysis in a Turkish Province. The Province of Tokat: a case study, New MEDIT, 9(3):76-80.

Krumbhar V., 2013, Some Critical Issues of Women Entrepreneurship in Rural India, European Academic Research, 1(2): 185-192.

Menard, Scott W., 2002, Applied Logistic Regression Analysis. $2^{\text {rd }}$ ed. Quantitative Applications in the Social Sciences, Sage Publications (CA), Paper 106.

Özdemir, G. and E.Yılmaz E. 2010. Kadın Girişimciliği ve Kooperatifler (Women Entrepreneurship and Cooperatives), Uluslararası II. Trakya Bölgesi Kalkınma-Girişimcilik Sempozyumu Bildiri Kitabı, Editörler: Muharrem ÖztelHüseyin Burgazoğlu, Kırklareli Üniversitesi Rektörlüğü, Baskı: Erkam Matbaası, İstanbul, s.71-79.
Öztürk, F. and A.T. Akkoç, 2013. Kadın Girişimciliğini Etkileyen Faktörler (The Factors Effecting Women Entrepreneurship), V International Congress on Entrepreneurship, (ICE2013),123128 , http://www.sdu.edu.kz/www/images/c/Homepage_pictures/04_A pril/procedia_ice2013_2-.pdf\#page $=123$

Parveen, K. and S.G.Hundekar 2012. NGOs and their Role in Development of Science - In Development of Rural Women Entrepreneurship, Res.J.Recent.Sci. 1:410-414

Saxena, S. 2012. Problems Faced By Rural Entrepreneurs and Remedies to Solve It, IOSR Journal of Business and Management (IOSRJBM),3(1):23-29.

Soysal, A., 2010. Türkiye'de Kadın Girişimciler: Engeller ve Fırsatlar Bağlamında Bir Değerlendirme, (Women Entrepreneurs in Turkey: an Assessment in the Context of Difficulties and Opportunitie), Ankara Üniversitesi SBF Dergisi, 65 (1):83-114

Soysal, A., 2013. Kırsal Alanda Kadın Girişimciliği: Türkiye İçin Durum Değerlendirmesi (Women's Entrepreneurship In Rural Areas: An Assessment For Turkey), Eskişehir Osmangazi Üniversitesi Ï̈BF Dergisi Nisan 2013, 8 (1):163-189.

Tamer, G., 2013. Dünya'ya Kıyasla Türkiye'de Kadın Girişimciliği (Women's Entrepreneurship in Turkey Compared to the World), international Conference On Eurasian Economies, SESSION 3C: Girişimcilik, $\quad$ s. $\quad 649-656$ http://www.eecon.info/papers/648.pdf

TÜiK, 2014. İsgücü İstatistikleri, Ankara, http://www.tuik.gov.tr/PreTablo.do?alt_id=1007 (12.12.2014).

Yetim N., 2002. Sosyal Sermaye Olarak Kadın Girişimciler: Mersin Örneği (Women Entrepreneurs as a Social Capital: Mersin Case), Ege Akademik Bakış Dergisi, 2 (1): 79-92. 